\title{
PENGARUH NILAI TUKAR TERHADAP HARGA SAHAM SETELAH INITIAL PUBLIC OFFERING (IPO)
}

\author{
Denny Andriana \\ denny.andriana@upi.edu \\ (Universitas Pendidikan Indonesia)
}

\begin{abstract}
ABSTRAK
Penelitian ini bertujuan untuk menguji pengaruh nilai tukar terhadap harga saham setelah Initial Public Offering (IPO) pada perusahaan yang terdaftar di Bursa Efek Indonesia. Pengamatan dilakukan terhadap 137 perusahaan yang melakukan IPO dalam kurun waktu tahun 2009 hingga tahun 2014. Metode purposive sampling yang dilakukan pada penelitian ini menghasilkan 78 perusahaan yang menjadi sampel penelitian. Teknik analisis data yang digunakan dalam penelitian ini adalah model regresi sederhana. Hasil pengujian membuktikan bahwa nilai tukar berpengaruh positif namun tidak signifikan terhadap harga saham setelah IPO. Nilai koefisien determinasi adalah $0.047(4,7 \%)$ yang menunjukkan bahwa variasi nilai tukar hanya dapat menjelaskan sebesar 4,7\% terhadap variasi harga saham setelah IPO. Sementara 95,3\% lainnya adalah variabel lain yang tidak disertakan dalam penelitian ini.
\end{abstract}

\section{Kata Kunci: Nilai Tukar, Harga Saham, Initial Public Offering, Regresi Sederhana}

\section{PENDAHULUAN}

Krisis ekonomi di tahun 2008 yang melanda banyak negara di dunia telah berdampak negatif terhadap perekonomian negara, termasuk Indonesia. Jumlah hutang swasta di Indonesia pasca krisis tahun 2008 mencapai sebesar 73.606 juta US Dollar (US\$) di tahun 2009 dan terus meningkat pada tahun 2010 hingga menembus angka 83.789 juta US\$ (Kementerian Keuangan dan Bank Indonesia, 2015).

Terlepas dari tingginya nilai hutang luar negeri tersebut, kondisi iklim investasi pada pasar modal di Indonesia sendiri sedikit banyaknya dipengaruhi oleh kondisi ekonomi makro. Nilai tukar Rupiah menjadi salah satu faktor ekonomi makro yang berhubungan dengan likuiditas karena perusahaan yang memiliki hutang luar negeri harus menyediakan pembayaran dalam bentuk mata uang asing.

Dampak melemahnya nilai tukar terhadap harga saham di pasar modal memang sangat memungkinkan, mengingat sebagaian besar perusahaan yang terbuka (Go-Public) di Bursa Efek Indonesia mempunyai utang luar negeri dalam bentuk valuta asing (Cahya, et al, 2015). Bodie, et al (2007) mengungkapkan bahwa faktor makro ekonomi yang dapat mempengaruhi harga saham, antara lain suku bunga, inflasi, dan nilai tukar. Sehingga jika kondisi nilai tukar Rupiah diperkirakan buruk, maka kemungkinan besar refleksi pada indeks harga saham yang akan menurun. Hal ini karena pelemahan kurs Rupiah terhadap mata uang asing merupakan sinyal negatif bagi investor sehingga akan mempengaruhi harga saham tersebut (Ang, 1997). Perubahan nilai tukar sendiri menjadi variabel yang 
paling dominan diperhatikan oleh investor untuk menempatkan dananya di pasar modal karena adanya capital gain dalam jangka pendek yang hendak diraih oleh investor (Nurhakim, 2010).

Namun begitu, hasil kajian teoritis terkait adanya pengaruh positif nilai tukar terhadap harga saham tidak tercermin dari hasil penelitian empiris yang beragam. Walaupun Wibowo (2012) dan Rachmadhanto dan Raharja (2014) dalam hasil penelitiannya menemukan adanya pengaruh positif nilai tukar terhadap harga saham, tidak demikian dengan hasil penelitian Pujawati, et al (2015), Wiradisastra (2015), dan Mardiyati dan Rosalina (2013) yang justru mengungkapkan hasil kajian empiris yang berbeda, yaitu bahwa nilai tukar berpengaruh negatif terhadap harga saham. Hasil yang berbeda tersebut mendorong peneliti untuk menguji lebih lanjut pengaruh nilai tukar terhadap harga saham.

Penelitian ini bertujuan untuk mengetahui adanya pengaruh nilai tukar terhadap harga saham setelah Initial Public Offering (IPO) pada perusahaan yang terdaftar di Bursa Efek Indonesia periode tahun 2009-2014. Hasil penelitian ini diharapkan dapat memberikan tambahan pengetahuan dan wawasan mengenai nilai tukar dan pengaruhnya terhadap harga saham setelah IPO pada perusahaan yang terdaftar di Bursa Efek Indonesia. Manfaat praktis penelitian ini adalah untuk memberikan informasi berguna bagi para pembaca yang tertarik dengan hal - hal yang berhubungan dengan nilai tukar dan harga saham perusahaan.

\section{KAJIAN PUSTAKA}

Teori pesinyalan (signalling theory) menjelaskan alasan perusahaan memberikan informasi laporan keuangan kepada pihak eksternal. Dorongan tersebut timbul karena adanya informasi asimetris antara perusahaan (manajemen) dengan pihak luar, dimana manajemen mengetahui informasi perusahaan yang relatif lebih banyak dan lebih cepat dibandingkan pihak luar seperti investor dan kreditor (Sari dan Zuhrotun, 2006). Asimetri informasi perlu diminimalkan agar perusahaan go public dapat menginformasikan keadaan perusahaan secara transparan kepada investor (Masykur, 2013).

Publikasi laporan keuangan tahunan misalnya, akan dapat memberikan informasi terkait pertumbuhan deviden maupun perkembangan harga saham sehingga para investor dapat menggunakan informasi tersebut sebagai sinyal dan dasar dalam menentukan arah investasi (Jogiyanto, 2000).

Beberapa penelitian terkait pengaruh nilai tukar terhadap harga saham, baik itu harga saham setelah IPO, tingkat pengembalian saham, maupun terhadap Indeks Harga Saham Gabungan telah banyak dilakukan. Beberapa penelitian yang jadikan referensi dan dasar dalam penelitian ini diantaranya dilakukan oleh Pujawati, et al (2015), Wiradisastra (2015), Rachmadhanto dan Raharja (2014), Mardiyati dan Rosalina (2013), dan Wibowo (2012). Para peneliti tersebut bertujuan untuk menemukan adanya pengaruh nilai tukar terhadap harga saham perusahaan.

Wibowo (2012) dalam penelitiannya menemukan adanya pengaruh positif nilai tukar terhadap harga saham. Hasil penelitian tersebut didukung oleh Rachmadhanto dan Raharja (2014) yang menemukan hasil yang serupa. Namun begitu, hasil penelitian yang berbeda ditunjukkan dari hasil uji empiris yang dilakukan oleh Pujawati, et al (2015), Wiradisastra (2015) dan Mardiyati dan 
Rosalina (2013) yang mengungkapkan bahwa nilai tukar memiliki pengaruh negatif terhadap harga saham.

Hasil temuan yang berbeda antar para penelti tesebut dalam membuktikan pengaruh nilai tukar terhadap harga saham mendorong dilakukannya penelitian ini. Perbedaan penelitian ini dengan penelitian sebelumnya terletak pada subyek penelitian, variabel yang digunakan dan rentang waktu pengamatan. Penelitian ini menggunakan variabel nilai tukar dan harga saham setelah IPO dengan subyek penelitian perusahaan yang terdaftar di Bursa Efek Indonesia untuk periode tahun 2009 - 2014.

Berdasarkan pada dasar teori dan latar belakang di atas, maka peneliti memiliki hipotesis sebagai berikut:

Nilai Tukar Berpengaruh Positif terhadap Harga Saham setelah Initial Public Offering

\section{METODE PENELITIAN}

Populasi dan Sampel Penelitian

Populasi dalam penelitian ini adalah seluruh perusahaan yang terdaftar di Bursa Efek Indonesia yang melakukan Initial Public Offering (IPO) periode tahun 2009 - 2014. Metode pemilihan sampel dalam penelitian ini dilakukan dengan pendekatan purposive sampling. Purposive sampling adalah teknik penentuan sampel dengan pertimbangan tertentu (Sugiyono, 2012). Adapun kriteria yang digunakan dalam pemilihan sampel dalam penelitian ini adalah sebagai berikut: (1) Perusahaan yang melakukan Initial Public Offering (IPO) pada tahun 2009-2014; (2) Perusahaan masih aktif dan terdaftar di Bursa Efek Indonesia sampai tahun 2014; (3) Melakukan Initial Public Offering (IPO) pada hari Senin-Rabu.

Berdasarkan kriteria yang telah ditetapkan, dari total pengamatan sejumlah 137 perusahaan, diperoleh 78 sampel perusahaan yang memenuhi kriteria. Perusahaan yang memenuhi kriteria tersebut dapat dilihat pada tabel 1 .

Tabel 1.

Jumlah Pengamatan Perusahaan

\begin{tabular}{ll}
\hline $\begin{array}{l}\text { Perusahaan yang melakukan Initial Public Offering (IPO) } \\
\text { pada tahun 2009-2014 }\end{array}$ & 137 Perusahaan \\
\hline Perusahaan yang tidak aktif & (4 Perusahaan) \\
\hline $\begin{array}{l}\text { Perusahaan yang melakukan Initial Public Offering (IPO) } \\
\text { selain hari Senin-Rabu }\end{array}$ & (55 Perusahaan) \\
\hline
\end{tabular}

Total Sampel Penelitian 78 Perusahaan

\section{Sumber : Bursa Efek Indonesia (diolah)}

\section{Variabel dan Pengukuran}

Variabel yang digunakan dalam penelitian ini adalah variabel bebas dan terikat. Variabel bebas merupakan variabel yang mempengaruhi atau yang menjadi sebab perubahannya atau timbulnya variabel dependen (terikat) (Sugiyono, 2012).

Variabel bebas dalam penelitian ini adalah nilai tukar. Nilai tukar atau kurs (foreign exchange rate) adalah harga mata uang yang berbeda di suatu negara relatif terhadap mata uang negara lain (Abimanyu dalam Sudi 2010; Triyono, 
2008). Nilai tukar yang digunakan untuk penelitian ini adalah nilai tengah dari kurs jual dan kurs beli mata uang Rupiah terhadap US Dollar.

$$
\text { Nilai Tukar }=\frac{\text { Kurs Jual }+ \text { Kurs Beli }}{2}
$$

Sementara variabel terikat (dependent variable) merupakan variabel yang dipengaruhi atau yang menjadi akibat, karena adanya variabel bebas (Sugiyono, 2012).

Variabel terikat dalam penelitian ini adalah harga saham setelah IPO. Harga saham dapat diartikan sebagai uang yang dikeluarkan untuk memperoleh bukti penyertaan atau pemilikan suatu perusahaan melalui mekanisme permintaan dan penawaran dipasar modal (Anoraga dan Pakarti, 2006; Sartono, 2001). Sementara itu, harga saham setelah IPO dapat dihitung dari nilai tengah dari harga saham pada hari 1 sampai hari 3 awal perdagangan di pasar sekunder. Adapun formula yang digunakan dalam menghitung Harga Saham setelah IPO dalam penelitian ini adalah sebagai berikut:

Harga Saham IPO =

$\underline{\text { Harga Closing Price pada hari } 1 \text { sampai } 3 \text { awal perdagangan di pasar sekunder }}$

\section{Teknik Analisis Data}

Teknik analisis data yang digunakan dalam penelitian ini adalah model regresi sederhana. Regresi sederhana digunakan untuk mengetahui pengaruh satu variabel bebas terhadap variabel terikat. Pengujian hipotesis dilakukan dengan menguji koefisien regresi dengan uji t. Model regresi sederhana ditunjukkan oleh persamaan berikut ini:

\section{Keterangan:}

$$
\hat{\mathbf{Y}}=\mathbf{a}+\mathbf{b X}+\mathbf{e}_{\mathbf{i}}
$$

$$
\begin{aligned}
& \hat{Y}=\text { Harga saham setelah IPO; } \\
& \mathrm{a}=\text { Konstanta; } \\
& \mathrm{b}=\text { Koefisien regresi; } \\
& \mathrm{X}=\text { Nilai tukar; } \\
& \mathrm{e}=\text { Error }
\end{aligned}
$$

\section{HASIL DAN PEMBAHASAN}

Hasil analisis regresi sederhana dengan alat uji $t$ untuk nilai tukar menunjukkan nilai koefisien beta sebesar 0.273. Tasil temuan dalam penelitian ini

\begin{tabular}{|c|c|c|c|c|c|}
\hline \multirow[t]{2}{*}{ Model } & \multicolumn{2}{|c|}{$\begin{array}{l}\text { Unstandardized } \\
\text { Coefficients }\end{array}$} & $\begin{array}{l}\text { Standardize } \\
\text { Coefficients }\end{array}$ & \multirow[t]{2}{*}{$\mathbf{t}$} & \multirow[t]{2}{*}{ Sig. } \\
\hline & B & Std. Error & Beta & & \\
\hline $1 \quad$ (Constant) & -1627.354 & 1390.033 & & -1.171 & .245 \\
\hline
\end{tabular}
menunjukkan arah koefisien positif yang memberikan implikasi bahwa ketika nilai tukar Rupiah mengalami peningkatan, maka akan diikuti oleh kenaikan harga saham setelah IPO untuk seluruh perusahaan yang terdaftar di Bursa Efek Indonesia periode tahun 2009 - 2014.

Tabel 2.

Hasil Olah Data Pengaruh Nilai Tukar terhadap Harga Saham Setelah IPO 


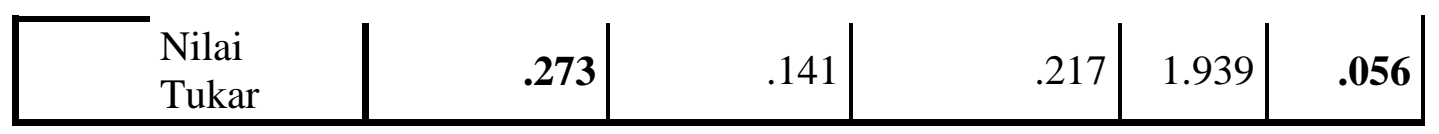

Dependent Variabel: Harga Saham setelah IPO

Pengaruh positif nilai tukar terhadap harga saham setelah IPO sesuai dengan teori yang diungkapkan oleh Tandelilin (2000) dan Madura (2006) yang menyatakan bahwa faktor-faktor ekonomi makro, seperti laju pertumbuhan inflasi, tingkat suku bunga dan fluktuasi nilai tukar mata uang (exchange rate) secara empirik telah terbukti mempunyai pengaruh terhadap kondisi pasar modal di beberapa negara. Menguatnya kurs Rupiah terhadap mata uang asing merupakan sinyal positif bagi ekonomi yang tengah mengalami inflasi.

Hasil penelitian ini senada dengan penelitian empiris yang dilakukan Rachmadhanto dan Raharja (2014) dan Wibowo (2012) yang menemukan adanya pengaruh positif nilai tukar terhadap harga saham. Namun demikian, hasil penelitian ini bertentangan dengan uji empiris yang dilakukan oleh Pujawati, et al (2015), Wiradisastra (2015) dan Mardiyati dan Rosalina (2013) yang mengungkapkan bahwa nilai tukar memiliki pengaruh negatif terhadap harga saham.

Adapun nilai signifikansi yang ditemukan dalam penelitian ini adalah sebesar 0.056, yang menandakan bahwa nilai tukar tidak berpengaruh signifikan terhadap harga saham setelah IPO. Rachmadhanto dan Raharja (2014) berpendapat bahwa tidak berpengaruhnya secara signifikan nilai tukar terhadap harga saham setelah IPO karena bisa jadi adanya perbedaan sasaran masingmasing perusahaan yang sebagian mengandalkan impor dan sebagian lagi pada kegiatan ekspor. Selain itu, beberapa investor jangka panjang menganggap bahwa dampak fluktuasi nilai tukar Rupiah hanya sementara sehingga tidak berpengaruh signifikan terhadap harga saham setelah IPO.

Sementara itu, nilai koefisien determinasi yang ditemukan dalam penelitian ini adalah sebesar 0.047 (4,7\%). Nilai ini menunjukkan bahwa variasi nilai tukar hanya dapat menjelaskan sebesar $4,7 \%$ terhadap variasi harga saham setelah IPO. Sementara 95,3\% lainnya dijelaskan oleh faktor lain yang tidak diungkapkan dalam penelitian ini.

Tabel 3.

Koefisien Determinasi

\begin{tabular}{|l|c|r|r|r|r|}
\hline Model & R & $\begin{array}{c}\text { R } \\
\text { Square }\end{array}$ & $\begin{array}{c}\text { Adjusted R } \\
\text { Square }\end{array}$ & $\begin{array}{c}\text { Std. Error of } \\
\text { the Estimate }\end{array}$ & $\begin{array}{c}\text { Durbin- } \\
\text { Watson }\end{array}$ \\
\hline 1 & $.217^{\mathrm{a}}$ & $\mathbf{. 0 4 7}$ & .035 & 1415.22338 & 1.391 \\
\hline
\end{tabular}

a. Predictors: (Constant), Nilai Tukar

b. Dependent Variable: Harga Saham Setelah IPO

\section{SIMPULAN}

\section{Simpulan}

Hasil penelitian menunjukkan bahwa nilai tukar berpengaruh positif namun tidak signifikan terhadap harga saham setelah IPO. Arah koefisien regresi menunjukkan nilai positif sebesar 0.273 dengan nilai signifkansi sebesar 0.056 . Sementara itu, nilai koefisien deteminasi yang ditemukan dalam penelitian ini adalah sebesar $0.047(4,7 \%)$. Nilai ini menunjukkan bahwa variasi nilai tukar 
hanya dapat menjelaskan sebesar 4,7\% terhadap variasi harga saham setelah IPO. Sementara 95,3\% lainnya dijelaskan oleh faktor lain yang tidak diungkapkan dalam penelitian ini.

\section{Saran}

Penelitian ini memiliki beberapa keterbatasan yang dapat dijadikan bahan pertimbangan untuk penelitian selanjutnya. Pertama, penelitian ini hanya menggunakan variabel nilai tukar sebagai variabel bebas untuk mengetahui pengaruhnya terhadap harga saham setelah IPO. Oleh karena itu, rendahnya nilai koefisien determinasi yang tercermin dengan persentase sebesar 4,7\%, menandakan bahwa masih terdapat beberapa faktor yang mempengaruhi harga saham setelah IPO, seperti suku bunga Sertifikat Bank Indonesia, inflasi, dan faktor ekonomi makro lainnya.

Kedua, penelitian ini hanya menggunakan data perusahaan yang melakukan IPO pada hari Senin hingga Rabu. Sehingga jumlah perusahaan yang dijadikan sampel belum cukup untuk mewakili keseluruhan perusahaan yang melakukan IPO dan tercatat di Bursa Efek Indonesia. Ketiga, penelitian ini hanya melakukan periode pengamatan selama kurun waktu tahun 2009 hingga tahun 2014. Periode pengamatan yang lebih panjang tentu akan memberikan hasil penelitian yang lebih mendalam.

\section{DAFTAR PUSTAKA}

Agus Sartono. (2001). Manajemen Keuangan Internasional. BPFE. Yogyakarta.

Ang, Robert. (1997). Buku Pintar Pasar Modal Indonesia. Jakarta. Mediasoft Indonesia.

Anoraga, P., dan Pakarti. (2006). Pengantar Pasar Modal. (Cetakan Pertama). Jakarta: PT. Rineka Cipta.

Bodie, Z., A. Kane, dan A. J. Marcus. (2007). Investment (7th Ed). New York: McGrow-Hill.

David Tri Rachmadhanto, dan Raharja. (2014). Analisis Pengaruh Faktor Fundamental Perusahaan dan Kondisi Ekonomi Makro Terhadap Tingkat Underpricing Saat Penawaran Umum Perdana (Studi Empiris pada Perusahaan Go Publik yang Terdaftar di Bursa Efek Indonesia Tahun 2008 - 2011). Diponegoro Journal of Accounting. Vol. 3, Nomor 4.

Ikmar Masykur. (2013). Faktor - Faktor yang Mempengaruhi Pengungkapan Kinerja Perusahaan di Website. Universitas Hasanuddin. Makasar.

Jogiyanto. (2000). Teori Portofolio dan Analisa Investasi. Yogyakarta:BPFE UGM.

Kementerian Keuangan dan Bank Indonesia. (2015). Statistik Utang Luar Negeri Indonesia. Vol. VI. Jakarta: Publikasi Bersama Kemenkeu dan BI.

Madura, Jeff. (2006). Keuangan Perusahaan Internasional. Edisi Kedelapan. Jakarta: Salemba Empat.

Nurhakim. (2010). Pengaruh Perubahan Nilai Tukar, Inflasi, Suku Bunga, dan Beta Terhadap Return Saham Jakarta Islamic Index pada Periode Bullish 
dan Bearish (Januari 2004 - Desember 2008). Universitas Islam Negeri Sunan Kalijaga. Yogyakarta

Putu Eka Pujawati., I Gusti Bagus Wiksuana., dan Luh Gede Sri Artini. (2015). Pengaruh Nilai Tukar Rupiah Terhadap Return Saham dengan Profitabilitas Sebagai Variabel Intervening. E-Jurnal Ekonomi dan Bisnis Universitas Udayana 4.04.

Putu Fenta Pramudya Cahya., I Wayan Suwendra., dan Fridayana Yudiaatmaja. (2015). Pengaruh Nilai Tukar Rupiah dan Inflasi Terhadap Indeks Harga Saham Sektor Properti dan Real Estate yang Tercatat di Bursa Efek Indonesia Tahun 2011-2013. E-Journal Bisma Universitas Pendidikan Ganesha Jurusan Manajemen. Volume 3.

Ratna Chandra Sari., dan Zuhrotun. (2006). Keinformatifan Laba Di Pasar Obligasi Dan Saham: Uji Liquidation Option Hypothesis. Simposium Nasional Akuntansi 9, Padang.

Satrio Wibowo. (2012). Pengaruh Nilai Tukar, Suku Bunga Sertifikat Bank Indonesia dan Indeks Saham Dow Jones Terhadap Indeks Harga Saham Gabungan Indonesia. Jurnal Bisnis dan Akuntansi. Vol. 14, No.2.

Sudi, B. (2010). Peranan Faktor Fundamental dalam Nilai Tukar Rupiah Terhadap Dolar Amerika Januari 2000 - Desember 2009. Sekolah Pascasarjana Universitas Indonesia. Jakarta. Tesis.

Sugiyono. (2012). Metode Penelitian Kuantitatif dan Kualitatif dan $R \& D$. Alfabeta.

Tandelilin, Eduardus. (2000) Pasar modal Indonesia: Problem dan Prospek. Wahana, Vol. 3, No.2.

Taufik Amirudin Wiradisastra. (2015). Pengaruh Likuditas dan Nilai Tukar Terhadap Harga Saham setelah IPO pada Perusahaan yang Terdaftar di Bursa Efek Indonesia Tahun 2009 sampai Tahun 2014. Universitas Pendidikan Indonesia. Skripsi.

Triyono. (2008). Analisis Perubahan Kurs Rupiah Terhadap Dollar Amerika. Jurnal Ekonomi Pembangunan. Vol. 9, Nomor 2.

Umi Mardiyati., dan Ayi Rosalina. (2013). Analisis Pengaruh Nilai Tukar, Tingkat Suku Bunga, dan Inflasi Terhadap Indeks Harga Saham (Studi Kasus Pada Perusahaan Properti yang Terdaftar di Bursa Efek Indonesia). Jurnal Riset Manajemen Sains Indonesia (JRMSI). Vol. 4, No. 1. 